\title{
PEMBERDAYAAN INDIVIDU MELALUI KONSEP LINK AND MATCH DALAM PERSPEKTIF PENDIDIKAN ISLAM
}

\author{
Arsyad $^{1}$, Wahyu Bagja Sulfemi ${ }^{2}$ \\ STKIP Muhammadiyah Bogor \\ Arsyad_20006@yahoo.com \\ wahyubagja@gmail.com
}

\begin{abstract}
Abstrak
Manusia dengan segala potensinya membutuhkan berbagai bentuk pendekatan untuk menemukan nilai fitrahnya. Bimbingan jasmani dan rohani berdasarkan hukum-hukum agama Islam menuju kepada terbentuknya kepribadian utama menurut ukuran-ukuran Islam merupakan substansi dari roses pendidikan Islam. Link and Match sebagai suatu konsep yang menawarkan integrasi antara luaran pendidikan dengan dunia kerja merupakan konsepsi yang yang relevan dengan eksistensi manusia sebagai makhluk sosial. Bertolak dari konsep manusia yang bersifat integral-holistik, maka sistem pendidikan dalam Islam lebih berorientasi pada persoalan dunia dan ukhrawi sekaligus, sehingga orientasi pendidikan ditekankan pada pengembangan seluruh potensi yang dimiliki oleh maunsia untuk menjalankan amanah dan tanggung jawabnya sebagai hamba khalifah di muka bumi ini. Dengan demikian, integrasi antara konsep link and Match dengan proses pendidikan pada aspek jasmani, akal dan ruhani dalam diri setiap individu dapat mengejawantahkan peran manusia yang sebenarnya sebagai wakil Allah di muka bumi.
\end{abstract}

Kata Kunci: Pemberdayaan Individu, Link and Match, Pendidikan Islam.

\section{PENDAHULUAN}

Pemberdayaan atau empowerment adalah proses membangun dedikasi dan komitmen yang tinggi sehingga organisasi atau individu itu bisa menjadi sangat efektif dalam mencapai tujuantujuannya dengan mutu yang tinggi. Dalam pengertian konvensional, konsep pemberdayaan sebagai terjemahan empowerment mengandung dua pengertian, yaitu (1) to give power or authority atau memberi kekuasaan, mengalihkan kekuatan, atau mendelegasikan otoritas ke pihak lain, (2) to give ability to atau to enable atau usaha untuk memberi kemampuan atau keberdayaan. (Randy R. W. dan Riant Nugroho, 2007). Pemberdayaan adalah proses kerja sama antara klien dan pelaksana kerja secara bersama-sama yang bersifat manual benefit. 
Daalm proses pengembangan dan perkembangan seseorang menjadi pribadi disebut individualisasi, karena proses perkembangan seseorang tersebut seluruh akan terwujud sebagai manusia dengan fitrahnyta, sehingga dapat mencapai kualitas tertentu dan mampu bertanggung jawab secara pribadi atas keberadaannya. Indiviudalisasi memusatkan perhatian secara individual pada proses pemeliharaan fitrah dan pengembangan SDM. Manusia sebagai makhluk sosial juga berarti setiap individu tidak mungkin hidup layak tanpa terkait dengan kelompok masyarakat manusia lainnya. Itulah sebabnya dalam masyarakat demokratik, masyarakat dan individu saling komplementer.

Untuk melakukan penguatan individu, maka diguilirkan konsep Link and Match sebagai salah satu bentuk respon pemerintah terhadap fenomena kehidupan dan peradaban manusia. Konsep keterkaitan dan kesepadanan atau Link and Match sebagai bentuk penguatan hubungan antara dunia pendidikan dan dunia kerja yang dicetuskan pada era Mendiknas RI. Prof. Dr. Wardiman Djojonegoro (1993-1998), tersebut yang menekankan pada lulusan lembaga pendidikan harus sejalan dengan kebutuhan dan bisa langsung terserap oleh dunia kerja. Saat itu wacana yang muncul adalah lulusan lembaga pendidikan hanya sekedar menyiapkan lulusan yang siap training, siap dimodifikasi, dan siap ditambahkan ilmu. Padahal tuntutan para pengguna lulusan adalah siap pakai, siap bekerja, dan sebagainya. Intinya industri tidak ingin hanya sekedar terkena beban kembali, dengan biaya yang cukup tinggi, untuk selain memberi gaji pada karyawan juga harus mengeluarkan dana yang cukup besar untuk kembali melatih. Prinsip implementasi Link and Match adalah adanya kerjasama seluruh stakeholders dunia pendidikan, dengan membuka diri dan mendukung lembaga pendidikan untuk memperkuat keahlian (kompentensi) peserta didk yang dibutuhkan dunia kerja, seperti memberi kesempatan yang seluas-luasnya pada peserta didik yang ingin magang (bekerja) di perusahaan tersebut, menjadi tenga pengajar tamu di lembaga pendidikan.

Secara konseptual menurut Djojonegoro menyatakan bahwa tolok ukur pendidikan, khususnya kejuruan yang efisien adalah; (1) mempersiapkan siswanya untuk jenis pekerjaan yang didasarkan atas kebutuhan tenaga kerja, (2) siswa mendapatkan pekerjaan sesuai dengan keterampilan yang telah dilatihkan (Wardiman Djojonegoro, 1999). Konsideran seperti itu, mengisyaratkan betapa pentingnya pengelolaan sistem pendidikan menengah yang dilaksanakan berdasarkan prinsip kemitraan, khususnya bagaimana mengaitkan kompetensi lulusan dengan dunia industri sebagai sasaran dunia kerja alumni bersangkutan. 
Namun demikian, konsep Link and Match sebagai bentuk penguatan lulusan pendidikan harus dimaknai sebagai proses pemanusiaan manusia dan sebagai sebuah proses pendidikan, dalam individu tentu tidak terlepas dari karakteristik nilai-nilai yang bergerak, dia harus kondusif bagi sebuah perubahan ke arah kesempurnaan, terbuka dan memuat aspek-aspek dialektis dalam dirinya, tanpa itu semua tidak layak disebut sebagai proses pendidikan, dan akan sulit melahirkan manusia yang memiliki keterpaduan antara aspek jasmani, akal dan ruhani dalam dirinya.

\section{PEMBAHASAN}

\section{Manusia dalam Perspektif Al-Qur'an}

Manusia adalah makhluk ciptaan Allah yang mempunyai kedudukan terhormat, mempunyai naluri makan, mempertahankan diri dan memperoleh keturunan. Manusia diwajibkan bekerja keras dan berpikir untuk memanfaatkan dan mengolah alam semesta, karena manusia sebagai khalifah Allah di bumi. Untuk menjaga manusia dari berperilaku menyimpang dari perintah Allah, maka Allah menurunkan al-Qur'an sebagai pedoman, supaya manusia terhindar dari godaan syaithan. Al-Qur'an wajib dipelajari, dipahami dan janji Allah pada orang-orang yang mempelajarinya dan orang yang berpendidikan akan ditingkatkan derajatnya di sisi Allah.

Konsep manusia dalam Islam diambil dari ayat Al-Qur'an dan Hadits. Menurut surat alMu'minun ayat 12-16, manusia diptakan Allah dari intisari tanah yang dijadikan nuhtfah dan disimpan di tampat yang kokoh. Kemudian nuthfah itu dijadikan darah beku, darah beku itu dijadian mudghah,, mudghah dijadikan tulang, tulang yang dibalut dengan daging dan kemudian dijadikan Allah makhluk lain, surat as-Sajadah ayat 7-9. Selanjutnya dijelaskan bahwa setelah kejadian manusia dalam kandungan mengambil bentuk, lalu ditiupkanlah ruh oleh Allah Swt. ke dalamnya dan dijadikannya pendengaran, penglihatan, dan perasaan. Hadits yang diriwayatkan Bukhari dan Muslim menyatakan bahwa ruh dihembuskan Allah Swt ke dalam janin setelah ia mengalami perkembangan 40 hari nuthfah, 40 hari darah beku, dan 40 hari mudhgah. (Harun Nasution 1995;37).

Berdasarkan ayat dan hadits di atas, jelas bahwa manusia terdiri dari dua unsur yaitu jasmani dan ruhani. Manusia tersusun dari unsur materi yaitu tubuh yang mempunyai hayat dan unsur imateri yaitu ruh yang mempunyai dua daya; daya rasa di dada dan daya pikir di kepala. Daya rasa jika diasah dengan baik, mempertajam hati nurani, daya pikir jika dilatih akan mempertajam penalaran. Dengan demikian, apabila dihubungkan ayat dan hadits dengan Al-Qur'an surah 
adz-Dzaari ayat 56, maka dapat disimpulkan bahwa manusia adalah makhluk Allah yang terdiri unsur jasmani dan ruhani yang berkewajiba untuk mengabdiNya. (lbadah).

Dalam struktur jasmaniah dan rohaniah manusia, Allah memberikan seperangkat kemampuan dasar yang memiliki kecenderungan berkembang dalam psikologi disebut potensialitas atau disposisi yang menurut aliran psikologi behaviorisme, disebut prepotence reflexes (kemampuan dasar yang secara otomatis dapat berkembang). Faham Behaviorisme bersumber dari sarjana psikologi dan pendidikan Amerika Serikat yang berpandangan bahwa memang manusia itu tidak dilahirkan menjadi baik atau buruk, sebagaimana pendapat Skinner yang menyatakan bahwa lingkungan sekitar menentukan perkembangan hidup seseorang, namun ia sendiri juga dapat mengubah lingkungan itu. Jika mempercayai paham John Lock sebagai dalil, bahwa bila anak sejak lahir berada dalam keadaan suci bersih bagaikan lilin (tabula rasa) yang secara pasif menerima pengaruh dari lingkungan eksternal, berarti tidak menghargai benihbenih potensial manusia yang dapat ditumbuhkembangkan melalui pengaruh pendidikan.

\section{Manusia dalam Perspektif Pendidikan Islam}

Pendidikan Islam adalah bimbingan jasmani, rohani berdasarkan hukum-hukum agama Islam menuju kepada terbentuknya kepribadian utama menurut ukuran-ukuran Islam. Dengan pengertian yang lain sering dikatakan bahwa kepribadian utama tersebut dengan istilah kepribadian muslim, yaitu kepribadian yang memiliki nilai-nilai agama Islam, memilih dan memutuskan serta berbuat berdasarkan nilai-nilai Islam, dan bertanggung jawab sesuai dengan nilai-nilai Islam. (Arifin, 1987; 10). Oleh karena suatu pematangan yang bertitik akhir pada optimalisasi perkembangan atau pertumbuhan baru dapat tercapai bila mana berlangsung melaui proses demi proses kearah tujuan akhir perkembangan atau pertumbuhannya.

Islam memandang bahwa pendidikan adalah hal yang sangat penting terutama dalam kaitannya untuk memahami, mengolah, memanfaatkan dan mensyukuri nikmat Allah swt. Pendidikan dan ilmu pengetahuan merupakan cahaya bagi kehidupan umat manusia sehingga perilaku manusia dapat membedakan mana yang bathil dan mana yang hak, mana yang halal dan mana yang haram. Visi pendidikan Islam adalah membentuk pribadi yang komprehensif melalui tiga komponen yaitu; fisik, akal dan ruhani, baik dalam wujud interaksi dengan dirinya maupun dengan lingkungannya. 
Konsep pendidikan Islam adalah pendidikan manusia seutuhnya, yaitu kebulatan integratif antara aspek jasmani, akal dan ruhani. Dengan kata lain, keseimbangan antara akal, ruhani dan keterampilan. Karena manusia memiliki struktur yang terdiri dari unsur jasmani dan ruhani, dalam struktur itu Allah memberikan kemampuan dasar yang dalam pandangan Islam disebut fithrah. Fithrah itu mengandung implikasi kependidikan dengan pandangan bahwa peserta didik akan dibina dan dikembangkan sesuai ajaran Islam melalui pendidikan dan pengajaran. Sebagai makhluk yang memiliki potensi untuk dikembangkan, baik dari segi jasmani, akal dan ruhani, maka pembentukan pribadi muslim yang terampil, cerdas dan bertakwa, akan membawa kepada keseimbangan hidup antara hati dan akal. Kehidupan seperti inilah yang ingin dicapai dalm pendidikan Islam.

Link and Match dalam pendidikan menekankan pada konsep keterkaitan antara lembaga pendidikan denagn dunia kerja, atau dengan kata lain Link and Match ini adalah keterkaitan antara pemasok tenaga kerja dengan penggunanya. Dengan adanya keterkaitan ini maka pendidikan sebaagi pemasok tenaga kerja dapat mengadakan hubunga-hubungan dengan dunia usaha/industri. Penekanan terhadap konsep link and match ini adalah keterpaduan antara lembaga pendidikan sebagai pemasok tenaga kerja dengan dunia kerja atau industri, sehingga lembaga pendidikan diorientasikan semata pada pemenuhan untuk dunia kerja. Dampak penekanan konsep Link and match dalam pendidikan yang tidak komprehensif, akan menimbulkan krisis dan masalah sosial, sebab tujuannya bukan untuk mengembangkan insan utuh yang mampu mandiri baik dalam pola pikir maupun pola zikir, akan tetapi lebih menekankan pada usaha pembentukan manusia onderdil atau alat bagi sistem produksi dan sitem ekonomi.

Krisis dan masalah sosial yang muncul pada generasi sekarang adalah kurangnya pendidikan yang menekankan pada aspek pendidikan nilai, pendidikan religius, pendidikan budi pekerti, dan pendidikan karakter. Hal ini terlihat pada beberapa kasus yang mencerminkan kehidupan masyarakat kurang mendapatkan pendidikan nilai bahkan berkembangnya prilaku baru yang sebelum era global tidak banyak muncul, kini cenderung meluas, seperti; meningkatnya kekerasan di kalangan masyarakat; penggunaan bahasa dan kata-kata yang memburuk, cenderung tidak menggunakan kata baku pada anak sekolah dan remaja; pengaruh peer-group (geng) yang kuat dalam tindak kekerasan, baik di sekolah seperti bully atau di luar sekolah seperti geng motor dan sebagainya; meningkatnya perilaku merusak diri seperti penggunaan 
narkoba, alkohol, dan seks bebas; semakin kaburnya pedoman moral baik dan buruk; rendahnya rasa tanggung jawab individu dan warga negara; dan membudayanya ketidakjujuran.

Konsep pendidikan Islam adalah upaya sadar dan terencana dalam menyiapkan peserta didik untuk mengenal, memahami, menghayati hingga mengimani, bertaqwa, dan berakhlak mulia dalam mengamalkan ajaran agama Islam dari sumber utamanya kitab suci Al Quran dan Hadits, melalui kegiatan bimbingan, pengajaran, latihan, serta penggunaan pengalaman, disertai tuntunan untuk menghormati penganut agama lain dalam hubunganya dengan kerukunan antar ummat beragama. Pendidikan tersebut merupakan proses pembentukan karakter yang memberikan dampak positif terhadap perkembangan emosional, spiritualitas, dan kepribadian seseorang. Mendidik dengan karakter tidak hanya mengenalkan nilai-nilai secara kognitif, tapi juga melalui penghayatan secara afektif, dan mengamalkan nilai-nilai tersebut secara nyata dalam kehidupan sehari-hari, ada olah pikir, hati, rasa, raga, batin, dan budi. Melalui pendidikan Islam yang menekankan pada bimbingan jasmani dan rohani berdasarkan hukum-hukum Islam menuju pada terbentuknya kepribadian utama menurut ukuran Islam. (Ahmad D. Marimba, 1990; 69).

Kesucian manusia biasanya dikaitkan dengan kata "fitrah". Di tinjau dari segi bahasa hal ini sesungguhnya kurang tepat karena pengertian fitrah, sebagaimana telah dijelaskan, ialah asal kejadian atau pola dasar penciptaan. Berbagai kemampuan dan kecenderungan ini lahir dalam bentuk yang sangat sederhana dan terbatas, kemudian saling mempengaruhi dengan lingkungan, sehingga tumbuh dan berkembang menjadi lebih baik atau sebaliknya. Maka kemampuan dan kecenderungan peserta didik itu tumbuh dan berkembang sesuai dengan pengaruh alam sekitarnya. Oleh karena itu pendidikan dan pengajaran itu penting, dan wajib memfungsikan akal sehingga bisa membedakan baik dan buruk. Nurcholish Madjid, mengatakan bahwa manusia harus kembali kepada nature-nya, yaitu fitrah-nya yang suci (Budhy Munawar Rachman, 2007; 156). Untuk itu, pendidikan memainkan peranan penting dalam rangka meningkatkan potensi manusia, jika pendidikan yang diterima berkesan, maka potensi manusia akan terus meningkat dan berkembang. Oleh itu, program pendidikan perlu dirancang dengan teliti dan berkesan untuk menghasilkan individu yang cemerlang, gemilang dengan potensi yang harus dikembangkan dalam diri manusia adalah; (1) potensi keimanan, (2) potensi keikhlasan, dan (3) potensi kesabaran. 
Dengan demikian, konsep Link and Match dalam pendidian harus memandang manusia sebagai mahkluk yang memiliki potensi dan sesuai dengan teori kependidikan yang menekankan tiga ranah pokok; yaitu kognitif, afektif dan psikomotorik, sebab kemuliaan manusia dapat ditinjau baik dari segi fisik maupun ruhaninya, karena ia adalah makhluk jasmani rohani. Pendidikan Islam diharapkan menghasilkan individu yang aktif membangun peradaban dan keharmonisan kehidupan, khususnya dalam memajukan peradaban bangsa yang bermartabat yang dilandasi dengan keimanan, takwa, dan akhlak. Manusia seperti itu diharapkan tangguh dalam menghadapi berbagai tantangan, hambatan, dan perubahan dalam di tengah masyarakat baik dalam lingkup lokal, nasional, regional maupun global.

\section{KESIMPULAN}

Berangkat dari analisis dan deskripsi terhadap konsep Link and Match dalam perspektif pendidikan Islam, maka kesimpulan dari uraian tersebut adalah;

1. Pemberdayaan individu melalui lulusan lembaga pendidikan yang penekanan pada Link and Match antara lembaga pendidikan dengan dunia kerja, atau keterkaitan antara pemasok tenaga kerja dengan penggunanya semata, maka akan menimbulkan krisis dan masalah sosial, sebab tujuannya bukan untuk mengembangkan insan utuh yang mampu mandiri baik dalam pola pikir maupun pola zikir, akan tetapi lebih menekankan pada usaha pembentukan manusia onderdil atau alat bagi sistem produksi dan sitem ekonomi.

2. Konsep Link and match harus sejalan dengan konsep manusia sebagai makhluk ciptaan Allah yang mempunyai kedudukan terhormat, mempunyai naluri makan, mempertahankan diri dan memperoleh keturunan. Manusia diwajibkan bekerja keras dan berpikir untuk memanfaatkan dan mengolah alam semesta, karena manusia sebagai khalifah Allah di bumi.

3. Bertolak dari konsep manusia yang bersifat integral-holistik, maka sistem pendidikan dalam Islam lebih berorientasi pada persoalan dunia dan ukhrawi sekaligus, sehingga orientasi pendidikan ditekankan pada pengembangan seluruh potensi yang dimiliki oleh maunsia untuk menjalankan amanah dan tanggung jawabnya sebagai hamba khalifah di muka bumi ini, link and Match dengan mengaitkan atau memadukan proses pendidikan pada aspek jasmani, akal dan ruhani dalam dirinya dengan peran manusia sebagai wakil Allah di muka bumi. 


\section{Referensi}

Al-Qur'an Al-Karim Departemen Agama RI, Al-Qur'an Dan Terjemahannya, Jakarta, 1981.

Arsyad, A., \& Sulfemi, W. Bminat Siswa Tentang Keadministrasian Dengan Hasil Belajar Administrasi Perkantoran. Edutecno, 9 (2), 40-50. 2014.

Arsyad, Arsyad. Pengembangan Keprofesian Berkelanjutan (PKB) Bagi Guru Melalui Program Induksi Guru Pemula (PIGP) Prosiding Seminar Nasional, 1 (1). 36-41. 2016

Arifin. HM, Ilmu Pendidikan Islam, Jakarta : Bumi Aksara, 1986, Cet. Ke-2.

, Pendidikan Islam Dalam Arus Dinamika Masyarakat, Jakarta : PT. Golden Trayon, 1987.

D. Marimba, Ahmad, Pengantar Filsafat Pendidikan Islam, Bandung ; Al-Ma;Arif, 1990).

Hasan Langgulung, Asas-Asas Pendidikan Islam, Jakarta : Pustaka Al-Husna, 1987, Cet. Ke-7.

Hasbullah, Dasar-Dasar Ilmu Pendidikan, Jakarta: Raja Grafindo Persada, 2005, Cet Ke-4.

Muhammad Qutub, Sistem Pendidikan Islam, Alih Bahasa Oleh : Drs. Salman Harun, Bandung : PT. Al-Ma'arif, 1979.

Muhammad Fadhil Al-Jamālī, Filsafat Pendidikan Dalam Al-Qur'an, Surabaya: Bina Ilmu, 1986.

Nasution Harun, Akal Dan Wahyu Dalam Islam, Jakarta : UI Press, 1992, Cet. Ke-3.

Nurcholish Madjid, Masyarakat Religius, Jakarta: Paramadina, 2000.

Randy R. W. Dan Riant Nugroho, 2007. Manajemen Pemberdayaan, Jakarta : PT Elex Media Komputindo, 2007.

Sulfemi, Wahyu Bagja. Pengaruh Persepsi Siswa Atas Kemampuan Pedagogik Guru Dan Motivasi Belajar Siswa Terhadap Prestasi Belajar Ilmu Pengetahuan Sosial Siswa (Survei Di SMK Swasta Kabupaten Bogor). Edutecno. 7 (2), 17-26. 2013.

Sulfemi, Wahyu Bagja. Pengaruh Motivasi Dan Lingkungan Sekolah Terhadap Prestasi Belajar Sejarah Di SMA Negeri Leuwilang Kabupaten Bogor. Fascho: Kajian Pendidikan Dan Sosial Kemasyarakatan 9 (2), 42-52. 2014.

Sulfemi, Wahyu Bagja. Pengaruh Metode Pembelajaran Kontekstual dan Penggunaan Media Video Pendidikan Terhadap Hasil Belajar IPS. Edutecno 13 (2), 1-10. 2015.

Sulfemi, Wahyu Bagja. Challenges Of Indonesian Teacher Competence In Dealing With Asean Economic Cummunity (AEC). Engglis Forum. 1 (1). 69-79. 2015.

Sulfemi, Wahyu Bagja. Kemampuan Pedagogik Guru. Prosiding Seminar Nasional. STKIP Muhammadiyah Bogor 1. (1). 71-83. 2015.

Sulfemi, Wahyu Bagja. Hubungan Antara Persepsi Guru Pada Kepemimpian Kepala Sekolah Dan Motivasi Guru Dengan Kinerja Guru Dalam Proses Pembelajaran Di SMA Negeri 1 Ciomas. Fascho: Kajian Pendidikan Dan Sosial Kemasyarakatan, 5 (1), 36-55. 2016. 
Sulfemi, Wahyu Bagja. Modul Pembelajaran Ilmu Sosial Dan Budaya Dasar. Bogor : STKIP Muhammadiyah Bogor. 2016.

Sulfemi, Wahyu Bagja. Hubungan Persepsi Peserta Didik Tentang Kompetensi Guru Mata Pelajaran Sejarah Dengan Hasil Belajar Mata Pelajaran Sejarah Di Kelas X SMA Negeri 1 Pamijahan Kabupaten Bogor. Fascho, 5 (2), 52-70. 2016.

Sulfemi, Wahyu Bagja. Perundang-Undangan Pendidikan. Bogor : Program Studi Administrasi Pendidikan STKIP Muhammadiyah Bogor. 2016.

Purwanto Ngalim, Ilmu Pendidikan Teoritis Dan Praktis, Bandung : PT. Rosdakarya, 1994, Cet. $\mathrm{Ke}-7$

Zakiyah Darajdat, Ilmu Pendidikan Islam, Jakarta: Bumi Aksara, 1992, Cet. Ke-2.

Wardiman Djojonegoro, Pengembangan Sumber Daya Manusia Melalui SMK, (Jakarta: PT. Balai Pustaka, 1999.

Yusfiriadi Dan Sulfemi, Wahyu Bagja. Penyelewangan Dana Dalam Dunia Pendidikan. Fascho 1 (1), 1-9. 2012. 